\title{
Pengaruh Isu Sosio-Saintifik dalam Meningkatkan Keterampilan Proses Sains pada Materi Larutan Elektrolit dan Non-Elektrolit
}

\author{
Bella Nur Farida*, Sunyono, Tasviri Efkar \\ FKIP Universitas Lampung, J1. Prof. Dr. Soemantri Brojonegoro No.1 \\ * email: bellafarida17@gmail.com, Telp:+6282278345586
}

\begin{abstract}
The Effect of Socio-Scientific Issues in Improving Science Process Skill on Electrolyte and Non-Electrolyte Solutions Topics. This research was aimed to describe the effect of socio-scientific issues on improving science process skills. The method used was quasi-experiment with pretest-postest control group design. The samples were the students from one of senior high school in Bandar Lampung, X MIA 4 as experiment class and X MIA 3 as control class, cluster random sampling technique was used in determining the samples. The effect of socio-scientific issues was analyzed using the difference between two average tests and the effect size test. The results of the research show that the science process skills of students in the experiment class were higher than in the control class. The effect size of socio-scientific issues as a "large" category. In conclusion, socioscientific issues had large and positive effects on improving students' science process skills on electrolyte and non-electrolyte solutions topics.
\end{abstract}

Keywords: science process skills, socio-scientific issues, electrolyte and nonelectrolyte solutions.

\begin{abstract}
Abstrak:Pengaruh Isu Sosiosaintifik dalam Meningkatkan Keterampilan Proses Sains pada Materi Larutan Elektrolit dan Non-Elektrolit. Penelitian ini bertujuan untuk mendeskripsikan pengaruh pembelajaran berbasis isu sosiosaintifik dalam meningkatkan keterampilan proses sains siswa. Penelitian ini menggunakan metode quasi eksperiment dengan desain penelitian pretest-posttest control group. Pengambilan sampel dilakukan dengan cluster random sampling didapatkan kelas X MIA 4 sebagai kelas eksperimen dan X MIA 3 sebagai kelas kontrol. Pengaruh pembelajaran berbasis isu sosiosaintifik dianalisis menggunakan uji perbedaan dua rata-rata dan uji effect size. Hasil penelitian menunjukkan keterampilan proses sains siswa pada kelas eksperimen lebih tinggi daripada kelas kontrol. Ukuran pengaruh pembelajaran berbasis isu sosiosaintifik berkategori "besar". Kesimpulannya, pembelajaran berbasis isu sosiosaintifik berpengaruh besar dan positif dalam meningkatkan keterampilan proses sains siswa pada materi larutan elektrolit dan non elektrolit.
\end{abstract}

Kata Kunci: keterampilan proses sains, isu sosiosaintifik, larutan elektrolit dan non-elektrolit. 


\section{PENDAHULUAN}

Kimia merupakan salah satu cabang darillmu Pengetahuan Alam. Ilmu pengetahuan alam berkaitan dengan cara mencari tahu tentang gejala alam secara sistematis.Ilmu pengetahuan alam berkaitan dengan cara mencari tahu tentang gejala alam secara sistematis, sehingga IPA bukan hanya penguasaan kumpulan pengetahuan yang berupa fakta-fakta, konsep-konsep, maupun prinsipprinsip saja tetapi juga merupakan suatu proses penemuan. Pendidikan IPA diharapkan dapat menjadi wahana bagi peserta didik untuk mempelajari diri sendiri dan alam sekitar, serta prospek pengembangan lebih lanjut dalam menerapkannya dalam kehidupan sehari-hari BSNP (dalam Efendi, 2012).

Pembelajaran kimia saat ini bukan hanya menenkankan pada pemahaman konsep saja, namun siswa juga saat ini untuk dapat meningkatkan suatu keterampilan untuk memecahkan suatu masalah yang ada kaitannya dengan sains di kehidupan sehari-hari. Jadi, keberhasilan dari pembelajaran kimia lebih bermakna apabila hasil yang diperoleh dari suatu pembelajaran dapat langsung di terapkan dalam kehidupan sehari-hari.

Mempelajari ilmu kimia memberikan manfaat yang sangat besar bagi manusia, karena hampir semua aspek dalam kehidupan seharihari berhubungan dengan ilmu kimia contohnya seperti makanan, minuman, pakaian,obat-obatan, perumahan, kendaraan, dan sebagainya (Sujana, Sopandi dan Mudzakir 2014).

Kimia dianggap sebagai salah satu mata pelajaran yang sulit dipahami oleh siswa, karena dalam
Pembelajaran kimia umumnya guru hanya memberikan materi dan latihan soal tanpa mengaitkan materi kimia yang dipelajari dengan masalah yang akrab dengan siswa dikehidupan sehari-hari. Kesulitan siswa tersebut menyebabkan rendahnya pemahaman siswa sehingga nilai yang diperoleh siswa pada mata pelajarankimia cenderung rendah (Sunyono, 2009). Rendahnya pemahaman dan nilai yang diperoleh siswa pada mata pelajaran kimia disebabkan oleh banyak faktor. Salah satu faktor yang berperan dalam keberhasilan pembelajaran kimia adalah keterampilan proses sains.

Keterampilan proses sains merupakan semua keterampilan yang diperlukan untuk memperoleh, mengembangkan, dan menerapkan konsep-konsep, prinsip-prinsip, hukum-hukum, dan teori-teori sains, baik berupa keterampilan mental, keterampilan fisik (manual), maupun keterampilan sosial (Nugraha, 2005).

Pembelajaran kimia dapat tercipta melalui interaksi aktif siswa dengan teman sejawat, guru, buku, sumber-sumber belajar yang relevan,dan alam sekitarnya (Amri dan Ahmadi, 2010), maka pembelajaran kimia seharusnya diarahkan kepada keterlibatan siswa secara aktif dengan lingkungannya melalui percobaan. Dalam melakukan ekperimen atau percobaan ini siswa dapat mengembangkan keterampilan proses sains seperti merumuskan hipotesis, melakukan percobaan, (observasi) pengambilan data, dan mengkomunikasikan hasil percobaan/ eksperimen secara lisan dan tertulis (Abrari, Meti dan Riezky, 2012).

Menurut Esler dan Esler (dalam Laili, 2016) keterampilan proses sains dikelompokkan menjadi dua, yaitu keterampilan proses sains dasar 
dan keterampilan proses sains terintegrasi. Keterampilan proses sains dasar siswa yaitu terdiri dari mengamati, inferensi, mengelompokkan, menafsirkan (interpretasi), menyimpulkan dan berkomunikasi. Keterampilan proses sains terintegrasi yaitu mengajukan pertanyaan, merumuskan masalah, membuat hipotesis, penyelidikan, membuat alat/bahan dan menerapkan konsep.

Berdasarkan dari hasil
penelitian yang dilakukan oleh
Hariyani (2014) menunjukkan
bahwa keterampilan proses sains
kelas X dalam merumuskan masalah,
membuat hipotesis, dan membuat
kesimpulan pada materi larutan
elektrolit dan non elektrolit
dikategorikan kurang terampil.

Rendahnya keterampilan proses sains siswa disebabkan karena selama proses pembelajaran, tidak semua guru membimbing siswa cara membuat hipotesis, merumuskan masalah, menentukan variabel danmembuat kesimpulan. Selain itu, metode yang sering digunakan oleh guru dalam proses pembelajaran yaitu metode ceramah tanpa mengikut sertakan siswa untuk melatih keterampilan proses sainsnya (Puspita, 2014).

Hal ini didukung dari hasil penelitian yang dilakukan oleh Fauziah (2015) bahwa pembelajaran kimia di sekolah masih banyak menggunakan metode ceramah dan kegiatan pembelajaran yang lebih berpusat kepada guru sehingga siswa kurang berperan aktif dalam kegiatan pembelajaran.

Berdasarkan pada hal tersebut diatas, maka perlu adanya upaya untuk dapat mengatasi permasalahan yang ada pada pembelajaran kimia.
Salah satu cara untuk mengatasi permasalahan ini adalah dengan memperbaiki dan meningkatkan mutu dalam proses pembelajaran kimia di kelas (Rakhmawan, Setiabudi dan Mudzakir, 2015).

Menurut Khishfe (dalam Putri, 2015), salah satu pendekatan yang dapat digunakan untuk menunjang pembelajaran adalah melalui isu sosiosaintifik. Pembelajaran dengan SSI (Socioscientific Issues) baik diterapkan, karena pada pembelajaran dengan SSI melibatkan permasalahan atau isuisu yang berkembang di masyarakat yang berkaitan erat dengan sains. Contoh masalah yang dekat dengan kehidupan sehari-hari yangdapat diangkat adalah mengenai dampak penggunaan alat setrum yang digunakan untuk menangkap belut. Masalah ini berkaitan dengan materi kimia yaitu pada materi larutan elektrolit dan non elektrolit yang berkaitan dengan sosial dan sains.

Penelitian Putriana (2018) menunjukkan bahwa pembelajaran menggunakan isu sosiosaintifik mampu meningkatkan literasi kimia dan metakognisi siswa pada materi larutan elektrolit dan non elektrolit. Penelitian yang dilakukan oleh Pambudi (2018) juga menunjukkan bahwa pembelajaran menggunakan isu sosiosaintifik mampu meningkatkan literasi kimia dan efikasi diri siswa pada materi larutan elektrolit dan non elektrolit, namun pada keterampilan proses sains siswa belum diteliti oleh Putriana dan Pambudi oleh karena itu maka dilakukan penelitian dengan tujuan mendeskripsikan "Pengaruh Pembelajaran Berbasis Isu Sosiosaintifik Dalam Meningkatkan Keterampilan Proses Sains Siswa 
Pada Materi Larutan elektrolit dan Non-Elektrolit".

\section{METODE PENELITIAN}

\section{Populasi dan Sampel}

Populasi pada penelitian ini adalah seluruh siswa kelas X MIA (Matematika dan Ilmu Alam) tahun pelajaran 2018/2019 yang tersebar dalam lima kelas. Sampel diambil secara acak dengan teknik cluster random sampling, sehingga mendapatkan 2 (dua) kelas penelitian penelitian sebagai sampel, yaitu kelas X MIA 4 yang terdiri dari 29 siswa sebagai kelas eksperimen dan kelas X MIA 3 yang terdiri dari 30 siswa sebagai kelas kontrol.

\section{Metode dan Desain Penelitian}

Pada penelitian ini digunakan metode penelitian kuasi eksperimen dengan Pretest Posttest Control Group Design (Fraenkel dan Wallen, 2012). Pada desain penelitian ini melibatkan perbedaan nilai pretes maupun postes pada kelas yang diteliti. Kelas eksperimen diberikan perlakuan berupa pembelajaran dengan menggunakan isu sosiosaintifik pada materi larutan elektrolit dan non-elektrolit, dan perlakuan untuk kelas kontrol berupa pembelajaran tanpa menggunakan isu sosiosaintifik pada materi larutan elektrolit dan non elektrolit.

\section{Perangkat Pembelajaran dan Instrumen Penelitian}

Perangkat pembelajaran yang digunakan pada penelitian ini adalah Silabus materi larutan elektrolit dan non-elektrolit, RPP (Rencana Pelaksanaan Pembelajaran) berbasis isu sosiosaintifik pada materi larutan elektrolit dan non elektrolit dan 2 jenis LKPD. Instrumen yang digunakan pada penelitian yaitu soal tes keterampilan proses sains pada materi larutan elektrolit dan non elektrolit yang terdiri dari 8 pertanyaan dalam bentuk uraian, data aktivitas siswa dan dengan lembar observasi keterlaksanaan pembelajaran isu sosiosaintifik.

\section{Teknik Analisis Data}

Analisis yang dilakukan pada penelitian ini adalah analisis validitas dan reliabilitas instrumen penelitian, analisis keterlaksanaan pembelajaran menggunakan isu sosiosaintifik dalam meningkatkan keterampilan proses sains siswa dan analisis ukuran pengaruh (effect size).

Validitas dan reliabilitas dianalisis menggunakan software SPSS 23.0 instrumen dianalisis berdasarkan perbandingan nilai $\mathrm{r}_{\text {hitung }}$ dan $\mathrm{r}_{\text {tabel }}$ dengan $\mathrm{n}$ sebesar 20 dan taraf signifikan sebesar 5\%, sehingga diperoleh nilai $r_{\text {tabel }}$ sebesar 0,4438. Reliabilitas ditentukan dengan menggunakan rumus Alpha Cronbach yaitu dengan membandingkan nilai $\mathrm{r}_{11}$ dan $r_{\text {tabel. Instrumen tes dikatakan }}$ reliabel jika nilai $r_{11} \geq r_{\text {tabel}}$.

Keterlaksanaan pembelajaran menggunakan isu sosiosaintifik dapat diukur melalui penilaian terhadap keterlaksanaan RPP yang memuat unsur-unsur pembelajaran SSI berdasarkan rumus menurut Sudjana (2005) :

$$
\begin{array}{r}
\left.\% \mathrm{Ji}=\frac{\Sigma \mathrm{ji}}{N} \times 100 \% \text { (Sudjana, } 2005\right) . \\
\text { Keterangan, } \% \mathrm{Ji} \text { adalah } \\
\text { persentase dari skor ideal pada }
\end{array}
$$


pertemuan ke-i, $\sum \mathrm{Ji}$ adalah jumlah skor setiap aspek pengamatan pada pertemuan ke-I dan $\mathrm{N}$ adalah skor maksimal. Selanjutnya, menghitung rata-rata persentase ketercapaian untuk setiap aspek pengamatan dari dua orang pengamat, serta menafsirkan data keterlaksanaan pembelajaran dengan tafsiran persentase ketercapaian pelaksanaan pembelajaran menurut Arikunto (2006) seperti pada Tabel 1.

Tabel 1. Kriteria ketercapaian pelaksanaan pembelajaran

\begin{tabular}{ll}
\hline Persentase & Kriteria \\
\hline $80,1 \%-100 \%$ & Sangat tinggi \\
$60,1 \%-80 \%$ & Tinggi \\
$40,1 \%-60 \%$ & Sedang \\
$20,1 \%-40 \%$ & Rendah \\
$0,0 \%-20 \%$ & Sangat rendah \\
\hline
\end{tabular}

Aktivitas siswa selama pembelajaran diukur menggunakan lembar observasi oleh observer. Analisis deskriptif terhadap aktivitas siswa dalam pembelajaran menggunakan tafsiran harga persentase menurut Ratumanan (2006) pada Tabel 2.

Tabel 2. Kriteria aktivitas siswa

\begin{tabular}{ll}
\hline Persentase & Kriteria \\
\hline $80,1 \%-100 \%$ & Sangat tinggi \\
$60,1 \%-80 \%$ & Tinggi \\
$40,1 \%-60 \%$ & Sedang \\
$20,1 \%-40 \%$ & Rendah \\
$0,0 \%-20 \%$ & Sangat rendah \\
\hline
\end{tabular}

Peningkatan keterampilan proses sains siswa ditunjukkan melalui nilai $n$-Gain, yaitu selisih antaraskor postes dan skor pretes dan dihitung berdasarkan rumusan menurut Hake (2012) dengan kriteria seperti pada Tabel 3 berikut :

Tabel 3. Kriteria Skorn-Gain

\begin{tabular}{cc}
\hline n-Gain & Kriteria \\
\hline$>0,7$ & Tinggi \\
$0,3<$ n-Gain $=0,7$ & Sedang \\
n-Gain $\leq 0,3$ & Rendah \\
\hline
\end{tabular}

Setelah itu dilakukan uji perbedaan dua rata-rata menggunakan SPSS versi 23.0 dengan melihat nilai signifikansi. Sebelum dilakukan uji perbedaan dua rata-rata maka dilakukan uji normalitas dan homogenitas.

Uji normalitas dimaksudkan untuk meyakinkan bahwa sampel benar-benar berasal dari populasi yang berdistribusi normal. Uji homogenitas untuk meyakinkan bahwa sampel memiliki varians yang homogen (Sudjana, 2005). Apabila data yang diperoleh berdistribusi normal dan varians homogen, maka dilakukan uji perbedaan dua ratarata (uji-t), yaitu uji independent sample test dengan menggunakan nilai $n$-Gain dari kedua kelas. Kriteria pengujian adalah terima $\mathrm{H}_{0} \mathrm{jika}$ nilai sig (2-tailed) $<0,05$ yang berarti bahwa rata-rata nilai $n$-Gain keterampilan proses sains pada kelas eksperimen lebih tinggi daripada rata-rata $n$-Gain keterampilan proses sains pada kelas kontrol, tolak $\mathrm{H}_{0} \mathrm{jika}$ sebaliknya. Uji ukuran pengaruh (effect size) digunakan untuk mengetahui seberapa besar pengaruh perlakuan terhadap sampel penelitian. Sebelum menghitung effect size, terlebih dahulu dicari nilai $\mathrm{t}$ yang diperoleh dari uji independent sample test pada nilai pretes dan nilai postes menggunakan rumus sebagai berikut :

$$
\mu^{2}=\frac{t^{2}}{t^{2}+d f}(\text { Jahjouh, 2014). }
$$

Keterangan $\mu^{2}$ adalah effect size, $t^{2}$ adalah kuadrat $t$ hitung dari uji-t, $d f$ adalah derajat kebebasan. 
Setelah diperoleh effect size, kemudian menginterpretasikan nilai tersebut dengan kriteria effect size menurut Dincer (2015) pada Tabel 4.

Tabel 4. Kriteria Effect Size

\begin{tabular}{ll}
\hline Effectsize $(\mu)$ & Kriteria \\
\hline$\mu \leq 0,15$ & Sangat kecil \\
$0,15<\mu \leq 0,40$ & Kecil \\
$0,40<\mu \leq 0,75$ & Sedang \\
$0,75<\mu \leq 1,10$ & Besar \\
$\mu>1,10$ & Sangat besar \\
\hline
\end{tabular}

\section{HASILDAN PEMBAHASAN}

\section{Validitas danReliabilitas}

Berdasarkan perhitunganyang telah dilakukan terhadap instrumen tes, hasil analisis validitas instrumen soal tes keterampilan proses sains siswa disajikan pada Tabel 5 sebagai berikut :

Tabel 5. Uji validitas soal tes

\begin{tabular}{lccc}
\multicolumn{4}{c}{ keterampilan proses sains } \\
\hline Soal & $\begin{array}{c}\mathrm{r}_{\text {hitun }} \\
\mathrm{g}\end{array}$ & $\mathrm{r}_{\text {tabel }}$ & $\begin{array}{c}\text { Keteranga } \\
\mathrm{n}\end{array}$ \\
\hline 1 & 0,896 & 0,4438 & Valid \\
2 & 0,788 & 0,4438 & Valid \\
$3(\mathrm{a})$ & 0,683 & 0,4438 & Valid \\
$3(\mathrm{~b})$ & 0,557 & 0,4438 & Valid \\
4 & 0,685 & 0,4438 & Valid \\
5 & 0,733 & 0,4438 & Valid \\
6 & 0,645 & 0,4438 & Valid \\
7 & 0,625 & 0,4438 & Valid \\
\hline
\end{tabular}

Berdasarkan data pada Tabel 5, terlihat bahwa 8 butir soal pretes/postes keterampilan proses sains memiliki $r_{\text {hitung }}$ lebih besar dari nilair $r_{\text {tabel }}\left(r_{\text {hitung }}>r_{\text {tabel }}\right)$. Hal tersebut menunjukkan bahwa soal pretes/postes keterampilan proses sains adalah valid pada materi larutan elektrolit dan non elektrolit dan dapat digunakan sebagai instrumen pengukuran keterampilan proses sains.

\begin{abstract}
Uji reliabilitas soal tes keterampilan proses sains menunjukkan nilai Alpha Cronbach $\left(\mathrm{r}_{11}\right)$ sebesar 0,773 dan menunjukkan bahwa nilai $r_{11} \geq r_{\text {tabel}}$, sehingga instrumen dinyatakan reliabel. Berdasarkan uji validitas dan reliabilitas, soal tes keterampilan proses sains adalah valid dan reliabel sehingga layak digunakan untuk mengukur keterampilan proses sains siswa.
\end{abstract}

\section{Analisis Keterlaksanaan Pembelajaran Isu Sosiosaintifik}

Kemampuan guru dalam mengelola pembelajaran diukur menggunakan Lembar Observasi Keterlaksanaan Guru dalam pengelolaan pembelajaran berbasis isu sosiosaintifik. Penilaian lembar observasi ini dilakukan oleh dua orang observer selama proses pembelajaran berlangsung. Adapun persentase keterlaksanaan pembelajaran isu sosiosaintifik dapat dilihat pada Tabel 6 .

\begin{tabular}{llr}
\multicolumn{1}{c}{ Berdasarkan } & \multicolumn{2}{c}{ data hasil } \\
observasi & keterlaksanaan \\
pembelajaran & berbasis isu \\
sosiosaintifik yang & diperoleh, rata-
\end{tabular}
sosiosaintifik yang diperoleh, ratarata persentase pembelajaran pada kelas eksperimen pada pertemuan pertama dan pertemuan kedua yang membahas LKPD 1 dengan persentase rata-rata keterlaksanaan pembelajaran isu sosiosaintifik masuk dalam kriteria "tinggi" dan pada pertemuan ketiga yang membahas LKPD 2 dengan persentase rata-rata keterlaksanaan pembelajaran masuk dalam kriteria "sangat tinggi".

Tabel 6. Persentase keterlaksanaan isu sosiosaintifik

Pertemuan Pengamatan Persentase




\begin{tabular}{|c|c|c|}
\hline \multirow[t]{2}{*}{1} & $\begin{array}{l}\text { Kegiatan } \\
\text { Pendahuluan }\end{array}$ & $78,12 \%$ \\
\hline & $\begin{array}{l}\text { Scientific } \\
\text { background }\end{array}$ & $75,00 \%$ \\
\hline \multirow[t]{6}{*}{2} & $\begin{array}{l}\text { Evaluation of } \\
\text { Information }\end{array}$ & $78,12 \%$ \\
\hline & $\begin{array}{l}\text { Local, } \\
\text { National and } \\
\text { Global } \\
\text { Dimension }\end{array}$ & $81,25 \%$ \\
\hline & $\begin{array}{l}\text { Decision } \\
\text { Making }\end{array}$ & $87,50 \%$ \\
\hline & Penutup & $75,00 \%$ \\
\hline & $\begin{array}{l}\text { Pengelola } \\
\text { Waktu }\end{array}$ & $83,37 \%$ \\
\hline & Skor & $79,90 \%$ \\
\hline \multirow[t]{10}{*}{3} & $\begin{array}{l}\text { Kegiatan } \\
\text { pendahuluan }\end{array}$ & $84,37 \%$ \\
\hline & $\begin{array}{l}\text { Scientific } \\
\text { background }\end{array}$ & $81,25 \%$ \\
\hline & $\begin{array}{l}\text { Evaluation of } \\
\text { Information }\end{array}$ & $87,50 \%$ \\
\hline & $\begin{array}{l}\text { Local, } \\
\text { National and } \\
\text { Global } \\
\text { Dimension }\end{array}$ & $81,25 \%$ \\
\hline & $\begin{array}{l}\text { Decision } \\
\text { Making }\end{array}$ & $81,25 \%$ \\
\hline & Penutup & $81,25 \%$ \\
\hline & $\begin{array}{l}\text { Pengelola } \\
\text { Waktu }\end{array}$ & $96,87 \%$ \\
\hline & Skor & $84,33 \%$ \\
\hline & $\begin{array}{l}\text { Rata-rata } \\
\text { keseluruhan } \\
\text { pertemuan }\end{array}$ & $82,11 \%$ \\
\hline & Kategori & $\begin{array}{r}\text { Sangat } \\
\text { Tinggi }\end{array}$ \\
\hline
\end{tabular}

Secara keseluruhan persentase keterlaksanaan pembelajaran berbasis isu sosiosaintifik pada kelas eksperimen mengalami peningkatan pada setiap pertemuannya. Berdasarkan kriteria tersebut maka dapat dinyatakan bahwa pembelajaran berbasis isu sosiosaintifik pada kelas eksperimen sudah terlaksana dengan baik. Pada kelas eksperimen yang diberikan pembelajaran berbasis isu sosiosaintifik yaitu kelas X MIA 4, pada pertemuan pertama, masih terjadi kesulitan dalam mengkondisikan kelas karena siswa belum terbiasa dengan pembelajaran berbasis isu sosiosaintifik yang sedang digunakan. Siswa masih sulit untuk memahami bahwa materi larutan elektrolit dan non elektrolit yang dekat dengan kehidupan dan lingkungan sosialnya. Beberapa siswa sudah berani untuk menyampaikan pendapatnya namun belum disertai dengan alasan yang mendukung pendapatnya tersebut serta interaksi antara guru dan siswa masih kurang. Pada pertemuan ini siswa sudah aktif dalam melakukan percobaan dan mengikuti arahan dari guru.

Pada pertemuan kedua, kondisi kelas sudah kondusif dan sudah mulai terbiasa dengan pembelajaran berbasis isu sosiosaintifik yang digunakan.Siswa sudah mulai berani menyampaikan pendapatnya.

Pada pertemuan ketiga, siswa terlibat aktif dalam setiap proses pembelajaran seperti, siswa yang menyampaikan pendapat menggunakan bahasa yang santun dan mudah dipahami ketika menyanggah pendapat/jawaban dari kelompok lain terkait dengan LKPD yang sedang dibahas dan memberikan solusi untuk isu sosiosaintifik yang sedang dibahas. (Murezhawati, Hairida dan Melati2017) yang menyatakan bahwa guru memiliki peran penting sebagai pendidik menentukan keberhasilan suatu proses pembelajaran menciptakan kondisi dansituasi yang memungkinkan siswa membentuk makna dari bahan-bahan pelajaran melalui suatu proses belajar. Juhji (2016) menyatakan bahwa kemampuan guru dalam mengelola 
pembelajaran sangat diperlukan, dimana tidak hanya berpengaruh pada hasil belajar siswa saja, tetapi dapat juga berpengaruh terhadap keterampilan proses siswa. Hal ini sejalan dengan penelitian Pambudi (2018), pembelajaran menggunakan isu sosiosaintifik mampu meningkatkan literasi kimia dan efikasi diri siswa pada materi larutan elektrolit dan non elektrolit.

\section{Analisis Data Penilaian Aktivitas Siswa}

Analisis penilaian terhadap keterampilan proses sains ini dilakukan pada kelas eksperimen yaitu pada kelas X MIA 4 yang menggunakan pembelajaran berbasis isu sosiosaintifik untuk melihat peningkatan aktivitas siswa dalam 3 pertemuan. Peningkatan aktivitas siswa ditunjukan pada Gambar 1.

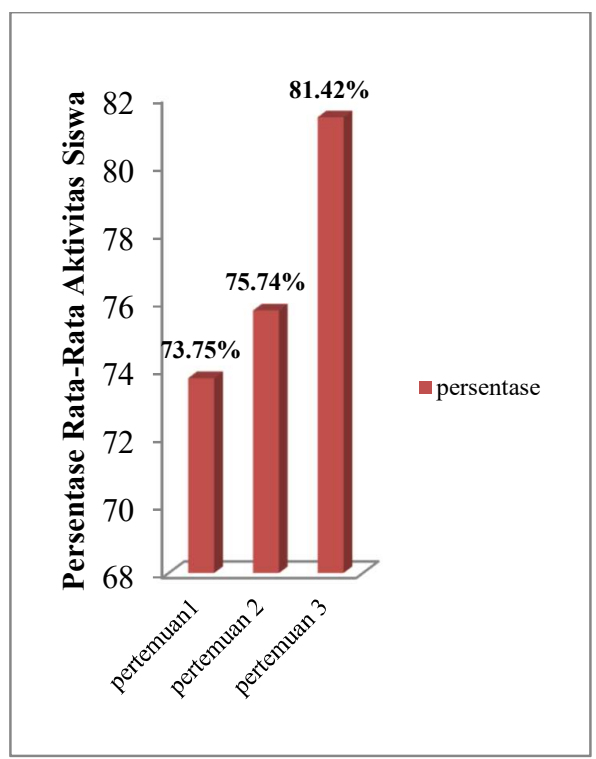

\section{Gambar 1.Persentase rata-rata aktivitas siswa}

Persentase rata-rata aktivitas siswa pada pertemuan pertama dan pertemuan kedua yang mempunyai kriteria "tinggi" dan pada pertemuan ketiga mempunyai kriteria "sangat tinggi”. Peningkatan aktivitas siswa ditunjukkan dengan terjadinya peningkatan aktivitas siswa disetiap pertemuan pada kelas eksperimen yang menggunakan pembelajaran berbasis isu sosiosaintifik.

\section{Analisis Data Keterampilan Proses Sains}

Keterampilan proses sains siswa diukur menggunakan soal pretes-postes tentang materi larutan elektrolit dan non elektrolit yang diberikan kepada seluruh siswa kelas X MIA 3 dan X MIA 4. Berikut hasil perhitungan dan persentase ketercapaian setiap indikator keterampilan proses sains siswa pada kelas X MIA 4 (kelas eksperimen) pada Gambar 2.

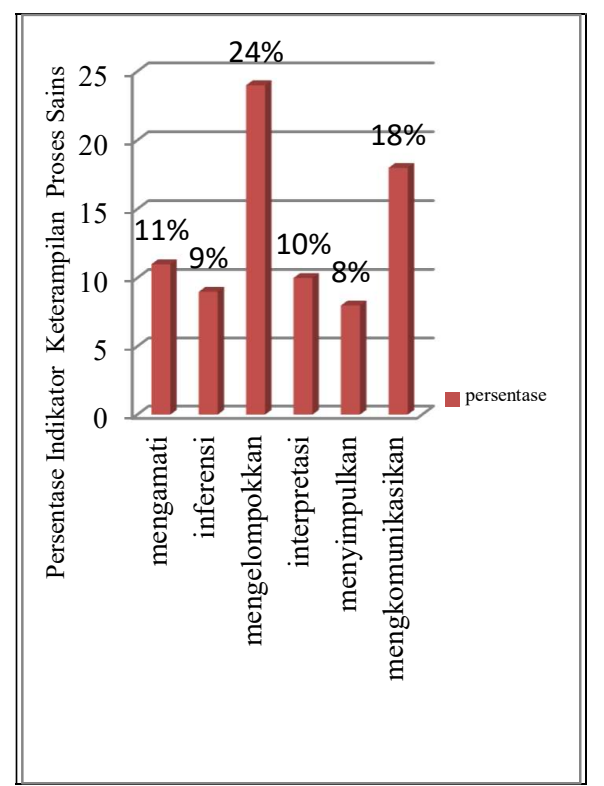

Gambar 2. Persentase ketercapaian indikator keterampilan proses sains pada kelas eksperimen

Berdasarkan pada Gambar 2, terlihat bahwa persentase paling tinggi pada ketercapaian indikator proses sains siswa yaitu pada indikator mengelompokkan dan persentase paling rendah pada 
ketercapaian indikator proses sains siswa yaitu pada indikator menyimpulkan.

Berikut ini adalah hasil perhitungan dan persentase ketercapaian setiap indikator proses sains siswa pada kelas X MIA 3 (kelas kontrol) yang disajikan pada Gambar 3.

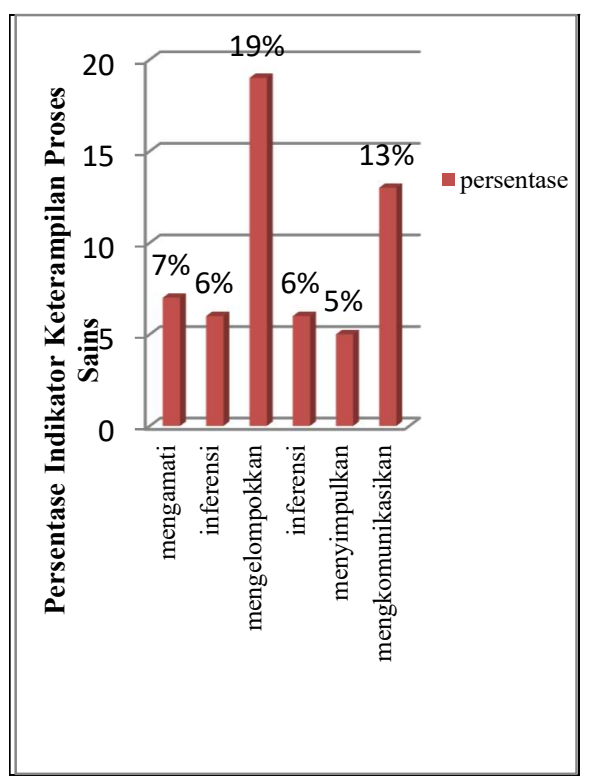

Gambar 3. Persentase ketercapaian indikator keterampilan proses sains pada kelas kontrol

Berdasarkan pada Gambar 3, terlihat bahwa persentase paling tinggi pada ketercapaian indikator proses sains siswa yaitu pada indikator mengelompokkan dan persentase paling rendah ketercapaian indikator keterampilan proses sains siswa yaitu pada indikator menyimpulkan.

Berdasarkan pada Gambar 2 dan Gambar 3 baik di kelas eksperimen maupun kelas kontrol, persentase ketercapaian indikator keterampilan proses sains paling tinggi yaitu pada indikator "mengelompokkan" ditandai dengan banyak siswa yang menjawab "benar" pada soal tes nomor 1 dan $3 \mathrm{a}$ dan persentase ketercapaian indikator paling rendah yaitu pada indikator "menyimpulkan" ditandai dengan banyak siswa yang menjawab "kurang tepat" pada soal tes nomor 7 . Berdasarkan hal tersebut ketercapaian keterampilan proses sains siswa telah terlatih dengan baik pada indikator mengelompokkan karena siswa banyak menjawab benar dan siswa banyak menjawab kurang tepat pada indikator menyimpulkan, ini membuktikan bahwa pada indikator menyimpulkan belum terlatih dengan baik pada siswa.

Peningkatan keterampilan proses sains ditunjukkan melalui skor n-Gain. Adapun rata-rata nilai pretes dan postes keterampilan proses sains siswa disajikan dalam Gambar 4.

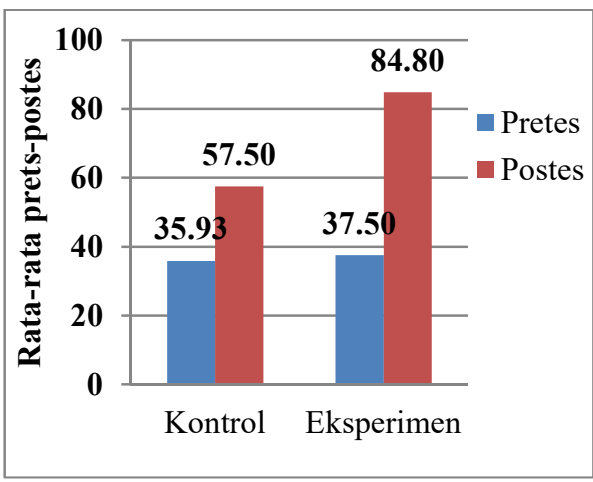

Gambar 4. Rata-rata nilai pretes dan postes keterampilan proses sains.

Berdasarkan Gambar 4, terlihat bahwa rata-rata keterampilan proses sains setelah pembelajaran lebih tinggi daripada sebelum pembelajaran baik pada kelas eksperimen maupun kelas kontrol. . Perbedaan rata-rata nilai pretes dan postes pada kelas kontrol dan kelas 
eksperimen menunjukkan bahwa terdapat peningkatan keterampilan proses sains pada masing-masing kelas. Adanya peningkatan keterampilan proses sains siswa di kelas eksperimen dan kelas kontrol digambarkan dengan rata-rata nGain keterampilan proses sains yang disajikan pada Gambar 5 berikut.

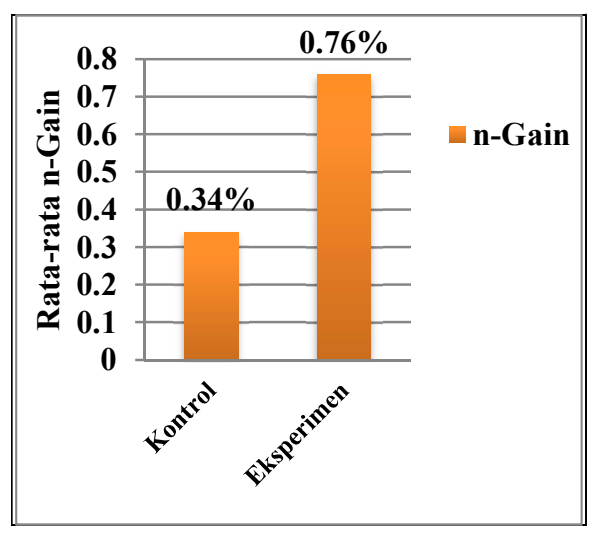

Gambar 5. Rata-rata n-Gain keterampilan proses sains

Berdasarkan Gambar 5, menunjukkan rata-rata $n$-Gain keterampilan proses sains siswa pada kelas eksperimen lebih tinggi daripada rata-rata n-Gain keterampilan proses sains siswa kelas kontrol. Hal ini menunjukkan bahwa pembelajaran dengan isu sosiosaintifik pada kelas eksperimen dapat meningkatkan keterampilan proses sains siswa lebih baik dibandingkan pembelajaran tanpa menggunakan isu sosiosaintifik pada kelas kontrol.

\section{Pengujian Hipotesis}

Hasil uji normalitas data keterampilan proses sains siswa pada kelas eksperimen dan kelas kontrol ditunjukkan pada Tabel 7.
Tabel 7. Uji normalitas

\begin{tabular}{|c|c|c|}
\hline \multirow[b]{2}{*}{ Data } & Nilai & sig. \\
\hline & $\begin{array}{l}\text { Kelas } \\
\text { eksperimen }\end{array}$ & $\begin{array}{l}\text { Kelas } \\
\text { kontrol }\end{array}$ \\
\hline Pretes & 0,200 & 0,111 \\
\hline Postes & 0,059 & 0,089 \\
\hline n-Gain & 0,200 & 0,172 \\
\hline
\end{tabular}

Berdasarkan data pada Tabel 7, terlihat bahwa nilai signifikansi yang diperoleh pada uji normalitas data keterampilan proses sains siswa lebih besar dari $0,05(>0,05)$ baik pada kelas eksperimen maupun kelas kontrol. Berdasarkan kriteria uji maka terima $\mathrm{H}_{0}$ dan tolak $\mathrm{H}_{1}$, yang menunjukkan data pretes, postes, dan n-Gain keterampilan proses sains siswa pada kelas eksperimen dan kelas kontrol berasal dari populasi yang berdistribusi normal Uji homogenitas data keterampilan proses sains kelas eksperimen dan kelas kontrol disajikan pada Tabel 8.

Tabel 8. Hasil Uji Homogenitas

\begin{tabular}{lll}
\hline \multirow{2}{*}{ Data } & \multicolumn{2}{c}{ Keterampilan Proses Sains } \\
\cline { 2 - 3 } & Nilai sig. & $\begin{array}{c}\text { Kriteria } \\
\text { Uji }\end{array}$ \\
\hline Pretes & 0,969 & Homogen \\
\hline Postes & 0,059 & Homogen \\
\hline n-Gain & 0,121 & Homogen \\
\hline
\end{tabular}

Berdasarkan Tabel 8, terlihat bahwa nilai signifikansi dari pretes, postes dan $n$-Gain yang diperoleh pada uji homogenitas data keterampilan proses sains siswa di kelas eksperimen dan kelas kontrol lebih besar dari 0,05. Berdasarkan kriteria uji maka terima $\mathrm{H}_{0}$ dan tolak $\mathrm{H}_{1}$, yang berarti berdasarkan hasil pengujian tersebut dapat diketahui 
bahwa kedua sampel berasal dari varians yang homogen.

Hasil uji perbedaan dua ratarata $n$ - Gain keterampilan proses sains diperoleh nilai signifikansi sebesar 0,00 . Nilai signifikansi yang diperoleh kurang dari 0,05 pada Uji$\mathrm{T}$ pada $n$-Gain keterampilan proses sains. Adapun hasil uji perbedaan dua rata-rata pretes-postes kelas eksperimen dan kelas kontrol dapat dilihat pada Tabel 9.

Tabel 9. Uji perbedaan dua rata-rata

\begin{tabular}{ccccc}
\hline kelas & data & Df & Nilait & $\begin{array}{l}\text { sig. } \\
2- \\
\text { taile } \\
\text { d) }\end{array}$ \\
\hline Eksperimen & $\begin{array}{c}\text { n- } \\
\text { Gain }\end{array}$ & 57 & 25,450 & 0,00 \\
\hline Kontrol & & & & \\
\hline
\end{tabular}

Berdasarkan Tabel 9, telah diketahui nilai t pada kelas kontrol dan kelas eksperimen, dimana nilai $\mathrm{t}$ ini yang selanjutnya akan digunakan untuk perhitungan effect size pada kelas kontrol dan kelas eksperimen.

\section{Effect Size (Ukuran Pengaruh)}

Uji effect size dilakukan untuk mengetahui seberapa besar pengaruh pembelajaran yang dilaksanakan pada kelas eksperimen dan kelas kontrol. Hasil uji effect size untuk data keterampilan proses sains siswa disajikan pada Tabel 10.

\begin{tabular}{|c|c|c|c|}
\hline Kelas & $\begin{array}{c}\text { Nilai } \\
\mathrm{T} \\
\end{array}$ & $\begin{array}{l}\text { Effect } \\
\text { Size }\end{array}$ & Kriteria \\
\hline Eksp. & 32,201 & 0,97 & Besar \\
\hline Kontrol & $\cdot 12,324$ & 0,85 & Besar \\
\hline
\end{tabular}

Berdasarkan Tabel 10, terlihat bahwa nilai $\mathrm{T}$ pada kelas eksperimen lebih besar dari kelas kontrol. Nilai ini yang kemudian digunakan untuk menghitung effect size. Berdasarkan uji effect size yang telah dilakukan, diperoleh hasil bahwa pada kelas eksperimen 97\% peningkatan keterampilan proses sains siswa dengan kriteria "besar" dipengaruhi oleh pembelajaran berbasis isu sosiosaintifik dan untuk kelas kontrol diperoleh hasil $85 \%$ peningkatan keterampilan proses sains siswa dengan kriteria "besar" dipengaruhi oleh pembelajaran.

Berdasarkan hal tersebut dapat disimpulkan bahwa pembelajaran pembelajaran berbasis isu sosiosaintifik berpengaruh lebih besar dalam peningkatan keterampilan proses sains siswa ditandai dengan nilai effect size pada kelas eksperimen lebih tinggi daripada nilai effect size pada kelas kontrol yang tanpa menggunakan pembelajaran berbasis isu sosiosaintifik atau pembelajaran konvensional

Hasil penelitian ini relevan dengan hasil penelitian yang dilakukan Putriana (2018), bahwa pembelajaran dengan menggunakan isu sosiosaintifik mampu meningkatkan literasi kimia dan metakognisi siswa dengan ukuran pengaruh dengan kriteria "besar" pada materi larutan elektrolit dan non-elektrolit. Hal ini juga sejalan dengan penelitian Pambudi (2018), pembelajaran menggunakan isu sosiosaintifik mampu meningkatkan literasi kimia dan efikasi diri siswa 
pada materi larutan elektrolit dan non-elektrolit.

\section{SIMPULAN}

Berdasarkan hasil analisis data dan pembahasan dari penelitian yang telah dilakukan, maka dapat disimpulkan bahwa pembelajaran berbasis isu sosiosaintifik berpengaruh dalam meningkatkan keterampilan proses sains siswa pada kelas eksperimen. Indikator keterampilan proses sains siswa yang paling mudah ditingkatkan dengan baik yaitu pada indikator mengelompokkan dan indikator yang sulit untuk ditingkatkan yaitu indikator menyimpulkan. Pada kelas eksperimen yang menggunakan pembelajaran berba isu sosiosaintifik ,indikator-indikator keterampilan proses sains meningkat dengan baik dibandingkan dengan peningkatan indikator-indikator keterampilan proses sains pada kelas kontrol. Ukuran pengaruh pembelajaran isu sosiosaintifik dalam meningkatkan keterampilan proses sains siswa pada materi larutan elektrolit dan non elektrolit memiliki kategori "besar".

\section{DAFTAR RUJUKAN}

Abrari, N.A.I., Meti, I., \& Riezky, M.P. 2012. The Influence of Guided Discovery Learning Methods Towards Science Skills Process in Class $\mathrm{X}$ of SMA Negeri 1 Teras Boyolali in Academic Year 2011/2012. Jurnal Pendidikan Biologi, 4(2): 421-428.

Amri, S., dan Ahmadi, I.K. 2010. Proses Pembelajaran Kreatif dan Inovatif dalam Kelas. Jakarta: Prestasi Pustaka.

Arikunto, S. 2006. Dasar-Dasar Evaluasi Pendidikan. Jakarta: Bumi Aksara.

Dincer, S. 2015. Effect of Computer Assisted Learning on Students' Achievement in Turkey: a Meta-Analysis. Journal of Turkish Science Education, 12(1): 99-118.

Efendi, A K. 2012. Efektivitas Model Pembelajaran Inquiry Terbimbing Dalam Meningkatkan Keterampilan Mengkonstruksi Argumen dan Memberikan Alasan Pada Materi Hidrolisis Garam. Skripsi. Jurnal Pendidikan dan Pembelajaran Kimia, Volume 1(1).

Fauziah, N., Sunyono, \& Efkar, T. 2015. Penerapan Pembelajaran Berbasis Multipel Representasi SiMaYang Tipe II untuk Menumbuhkan Model Mental dan Penguasaan Konsep Larutan Elektrolit dan Nonelektrolit Siswa. Jurnal Pendidikan dan Pembelajaran Kimia, (1): 172-183.hysic

Fraenkel, J. R. and Wallen, N. E. 2008. How to Design and Evaluate Research in Education. New York: McGraw-Hill Inc.

Hake, R.R. 2002. Relationship of Indiviual Student Normalized Learning Gains in Mathematics with Gender, High School, Physics, and Pre Test Score in Mathematics and Spatial Visualization. Physics Education Research Conference

Hariyani, C., Masriadi, \& Sartika, R.P. 2014. Deskripsi Keterampilan Proses Sains 
Siswa Kelas X SMK Negeri 1 Pontianak. Jurnal Pendidikan dan Pembelajaran, 5(12): 1628.

Jahjuoh, Y. M. 2014. The Effectiveness of Blended ELearning Forum in Planning for Science Instruction. Journal of Turkish Science Education, 11(4): 3-16.

Juhji. 2016. Peningkatan Keterampilan Proses Sains Siswa melalui Pendekatan Inkuiri Terbimbing. Jurnal Penelitian dan Pembelajaran IPA, 2 (1): 58-70.

Laili, I., 2016. Pengembangan Assesmen Keterampilan Proses Sains pada Materi Larutan Penyangga. Jurnal Pendidikan dan Pembelajaran Kimia, 4(3): 1097-1100.

Murezhawati, E., Hairida, dan Melati, H.A. 2017. Peningkatan Keterampilan Proses Sains SMA dengan Model Pembelajaran PredictObserve-Explain Materi Hidrolisis Garam. Jurnal Pendidikan dan Pembelajaran, 6(8) : 1-11

Nugraha, A.W. 2005.Penerapan Pendekatan Keterampilan Proses IPA pada Praktikum Kimia Fisika II di Jurusan Kimia FMIPA UNIMED melalui Kegiatan Praktikum Terpadu, Jurnal Penelitian Bidang Pendidikan, 11(2): 107-112.

Pambudi, F S . 2018. Pengaruh Penggunaan Isu Sosiosaintifik Dalam Meningkatkan Kemampuan Literasi Kimia dan Efikasi Diri Siswa Pada Materi
Larutan Elektrolit dan Non Elektrolit. Jurnal Pendidikan dan Pembelajaran, 2(2).

Puspita, D. R. 2014. Deskripsi Keterampilan Proses Sains Siswa melalui Metode Praktikum Materi Larutan Penyangga Kelas XI MIA. Jurnal Pendidikan Kimia Jurusan Pendidikan Matematika dan Ilmu Pengetahuan Alam Universitas Tanjungpura Pontianak, 4(1): 56-60.

Putri, C. D. S. 2015. Pengaruh Pembelajaran Berbasis Hakikat Sains terhadap Pengambilan Keputusan dan Pandangan Siswa tentang Hakikat Sains Melalui Isu Sosiosaintifik. (Skripsi). Bandung: UPI.

Putriana. 2018. Pengaruh Penggunaan Isu Sosiosaintifik Dalam Meningkatkan Literasi Kimia dan Metakognisi Siswa Pada Materi Larutan Elektrolit dan Non Elektrolit. Jurnal Pendidikan dan Pembelajaran, 2(2).

Rakhmawan, A., Setiabudi, A., dan Mudzakir, A. 2015. Perancangan Pembelajaran Literasi Sains Berbasis Inkuiri pada Kegiatan Laboratorium. Jurnal Penelitian dan Pembelajaran IPA, 1(1): 143152.

Ratumanan. 2006. Penilaian Kinerja Siswa. Yogyakarta: Pustaka Belajar.

Sudjana, N. 2005. Metode Statistika. Bandung: Transito.

Sujana, A., Permanasari, A., Sopandi, W., dan Mudzakir, A. 2014. Literasi Kimia Mahasiswa PGSD dan Guru IPA Sekolah Dasar. Jurnal Pendidikan IPA Indonesia, 3(1): 5-11. 
Sunyono, Wirya, I. W., Suyanto, E., dan Suyadi, G. 2009. Identifikasi Tentang Masalah Kesulitan dalam Pembelajaran Kimia SMA Kelas X di Propinsi Lampung. Journal Pendidikan MIPA, 10(2): 918. 